\title{
Effect of Nitrogen Load and Water Temperature on Treatment Efficiency of Anoxic Reactor Using Submerged Bed Process
}

\author{
TSUNEO YOSHINO, TOHRU IYO, and SHIGERU OHNO \\ School of Hygienic Sciences, Kitasato University. \\ /1-15-1, Kitasato, Sagamihara, Kanagawa, 228 Japan
}

\begin{abstract}
The effects of nitrogen load and water temperature on the treatment efficiency were studied using an anoxic reator equipped with a lace-like contact media. Experiments were conducted under various nitrate nitrogen $\left(\mathrm{NO}_{3}-\mathrm{N}\right)$ loads and water temperatures. Temperature coefficients $(\theta)$ of $1.046-1.064$ were calculated. An equation expressing the relationship between $\mathrm{NOx}-\mathrm{N}$ removal efficiency, the $\mathrm{NOx}-\mathrm{N}$ load and water temperature was obtained. From the equation, the $\mathrm{NOx}-\mathrm{N}$ load that allows a high $\mathrm{NOx}-\mathrm{N}$ removal efficiency in the anoxic reactor can be estimated, and the value was greatly effected by water temperature. Denitrification rates of $2.4-4.5 \mathrm{mg}-\mathrm{N} / \mathrm{g}-\mathrm{SS} \cdot \mathrm{hr}$ under water temperature of $30^{\circ} \mathrm{C}$ were obtained.
\end{abstract}

Key words : denitrification, submerged bed process, nitrogen load, water temperature

\section{INTRODUCTION}

In order to reduce the pollutant level in daily sewage, the demand for high-efficiency treatment is increasing even in small-scale onsite household wastewater treatment systems. In the case of small scale waste water treatment facilities using a biological nitrogen removal process, a submerged bed process is effective considering the variations in the flow of influent waste water.

Biological nitrogen removal treatment is generally affected by factors such as the F/M ratio, the $\mathrm{BOD} / \mathrm{N}$ ratio of the influent water, hydraulic retention time, water temperature and $\mathrm{pH}$ inside the reactor. We conducted an bench-scale experiment to examine the effects of nitrogen load and water temperature on the nitrogen removal efficiency of an anoxic reactor using a submerged bed process, which removes the nitrified nitrogen through denitrification.

\section{MATERIALS AND METHODS}

\section{Experimental apparatus A schematic pre-} sentation of the apparatus used in the experiment is shown in Fig. 1. The anoxic reactor was an angular tank made of transparent vinyl chloride with an effective capacity of $1 l$ and an effective depth of $28 \mathrm{~cm}$. The center of the reactor was divided into two compartments by a dividing wall. The two compartments were connected by a slot at the bottom. No stirrer was placed in the reactor. Water was circulated by a forced flow which ensured adequate contact with the contact medium. 


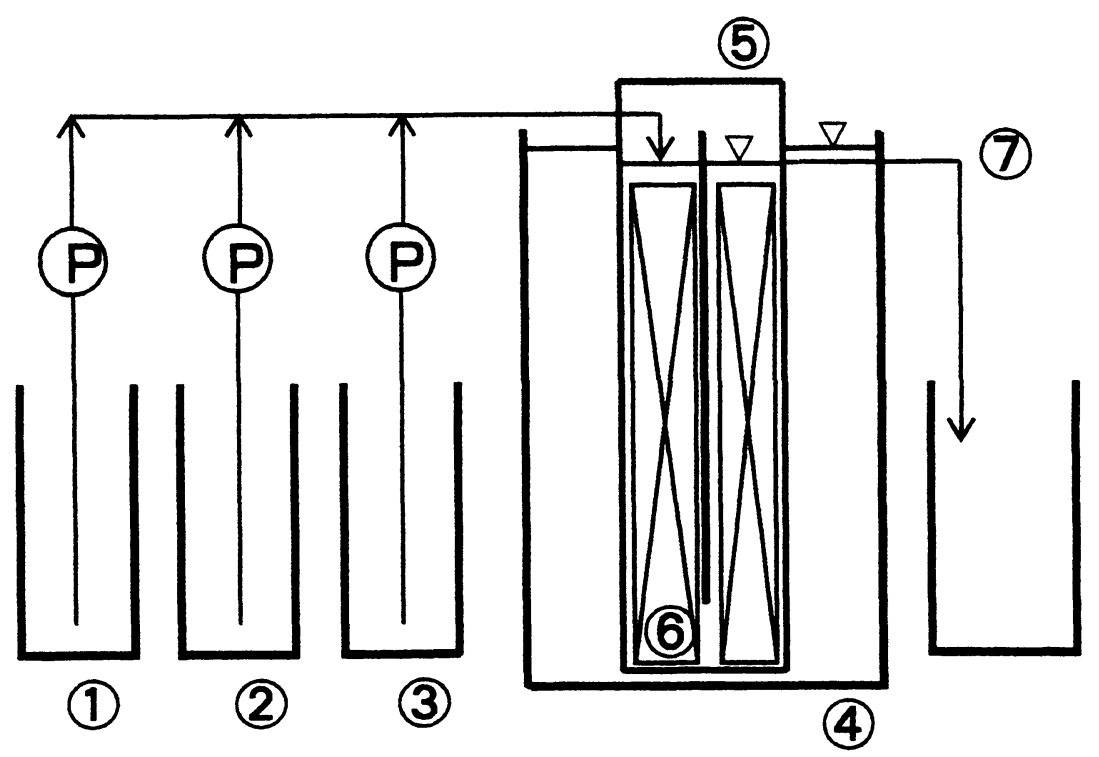

Fig.1 Experimental apparatus. (1), tap water; (2), concentrated wastewater; (3), $\mathrm{NaNO}_{3}$ solution; (4), thermostated water bath; (5), anoxic reactor; (6), contact media; (7), effluent.

Table 1 Experimental conditions

\begin{tabular}{|c|c|c|c|}
\hline Run & 1 & 2 & 3 \\
\hline Influent flow rate & 16 & 8 & 4 \\
\hline $\mathrm{HRT}^{*}$ & 1.5 & 3 & 6 \\
\hline Reator volume & 1 & 1 & 1 \\
\hline $\mathrm{NO}_{3}-\mathrm{N}$ loading rate & 0.24 & 0.12 & 0.06 \\
\hline Influent $\mathrm{NO}_{3}-\mathrm{N}$ concentration $(\mathrm{mg} / l)$ & 15 & 15 & 15 \\
\hline Influent BOD concentration & 45 & 45 & 45 \\
\hline
\end{tabular}

※hydraulic retention time

\section{Table 2 Composition of wastewater}

\begin{tabular}{lr}
\hline Glucose & $1200 \mathrm{mg} / l$ \\
Glutamic acid & $1200 \mathrm{mg} / l$ \\
$\mathrm{NH}_{4} \mathrm{Cl}$ & $1050 \mathrm{mg} / l$ \\
$\mathrm{CaCl}_{2} \cdot 2 \mathrm{H}_{2} \mathrm{O}$ & $60 \mathrm{mg} / l$ \\
$\mathrm{MgSO}_{4} \cdot 7 \mathrm{H}_{2} \mathrm{O}$ & $40 \mathrm{mg} / l$ \\
$\mathrm{KCl}$ & $60 \mathrm{mg} / l$ \\
$\mathrm{KH}_{2} \mathrm{PO}_{4}$ & $90 \mathrm{mg} / l$ \\
$\mathrm{NaHPO}_{4} \cdot 12 \mathrm{H}_{2} \mathrm{O}$ & $230 \mathrm{mg} / l$ \\
$\mathrm{FeCl}_{3} \cdot 6 \mathrm{H}_{2} \mathrm{O}$ & $10 \mathrm{mg} / l$ \\
$\mathrm{NaHCO}$ & \\
& $2000 \mathrm{mg} / l$ \\
\hline $\mathrm{BOD}$ & $2000 \mathrm{mg} / l$ \\
$\mathrm{~T}-\mathrm{N}$ & $388 \mathrm{mg} / l$ \\
$\mathrm{~T}-\mathrm{P}$ & $40 \mathrm{mg} / l$ \\
\hline
\end{tabular}

A frame consisting of stainless steel wire was placed in each compartment. Four lace-like contact media each measuring $25 \mathrm{~cm}$ were longitudinally placed on the flame to fill the compartments. The capacity of the filling portion was $0.85 l$.

The lace-like contact media consisted of fine vinylidene chloride thread knit in lace-like fashion (Commercial Name: Ring Lace) characterized by high physico-chemical stability ${ }^{1)}$.

The reactor was placed in a thermostated water bath. Sodium nitrate solution $(500 \mathrm{mg} / l$ as $\mathrm{NO}_{3}-\mathrm{N}$ ) and synthetic waste water (BOD 2000 $\mathrm{mg} / l$ ) were diluted with tap water to experimental conditions as shown in Table 1 using peristaltic pumps and supplied continuously 6 to 
the reactor. The synthetic waste water was prepared as in Table $2^{2)}$ and autoclaved before use. The tap water was flushed with nitrogen gas for approximately 8 hours to reduce the dissolved oxygen to $1 \mathrm{mg} / l$ or low.

Experimental conditions Three anoxic reactor systems were used, each set at experimental conditions as in Table 1 . The effects of water temperature at the experimental conditions shown in Table 1 were also examined by setting water temperatures at 10,20 and $30^{\circ} \mathrm{C}$.

At the beginning of the experiment, $1 \mathrm{~g}$-SS of activated sludge obtaind from the aeration tank of a domestic waste water treatment facility using conventional activated sludge process was seeded to the contact media in each of the reactor systems. Influent was supplied to each reactor at the conditions shown in Table 1 at the water temperature of $30^{\circ} \mathrm{C}$ for about two months. Following stabilization of effluent NOx $-\mathrm{N}$, the experiments were started.

The experiments were carried out at the water temperature of $30^{\circ} \mathrm{C}$ followed by $20^{\circ} \mathrm{C}$ and then by $10^{\circ} \mathrm{C}$. On changing the water temperature, an interval of about 1 week was placed before the next experiment to allow the stabilization of effluent $\mathrm{NOx}-\mathrm{N}$. After the end of the experiment at the water temperature of $30^{\circ} \mathrm{C}$, attached biomass was removed from the contact media of each reactor to estimate SS, followed by reapplication. $1 \mathrm{~g}$-SS of attached biomass was seeded to another reactor.

Sample analysis Treatment in each system was continued for approximately 10 days during which influent and effluent was sampled every two days for analysis.

Samples were analyzed for $\mathrm{NO}_{2}-\mathrm{N}, \mathrm{NO}_{3}-\mathrm{N}$, $\mathrm{BOD}, \mathrm{pH}$ and alkalinity according to the Stndard Methods for the Examination of Waste Water ${ }^{3)}$.

\section{RESULTS AND DISCUSSION}

Treatment results Based on the results of experiments, properties of the influent are shown in Table 3 and those of the effluent are shown in Table 4. Values in the Tables are expressed as means ( $\mathrm{pH}$ as megian). Measurments were repeated 5 times in Experiment 1 and 2, 4 times in Experiment 3.

As shown in Table 4, the total concentration of $\mathrm{NO}_{2}-\mathrm{N}$ and $\mathrm{NO}_{3}-\mathrm{N}$ of the effluent $(\mathrm{NOx}-\mathrm{N})$ became higher as the water temperature decreased, suggesting a profound influence of water temperature on denitrification efficiency. Even at the same water temperature, $\mathrm{NOx}^{-} \mathrm{N}$ concentration of the effluent became higher as the $\mathrm{NO}_{3}-\mathrm{N}$ load grew larger, suggesting a change of denitrification efficiency according to the condition of loading.

While the influent showed $\mathrm{pH} 7.2-7.6$ and alkalinity $63-80 \mathrm{mg} / l$, the corresponding values in the effluent was $7.5-8.1$ and $92-149 \mathrm{mg} / l$, indicating rises of both values during the process of treatmemt. The ratio calculated by dividing the increment of alkalinity by the ammount of removed $\mathrm{NO}_{3}-\mathrm{N}$ was $4.7-8.8$.

Influent BOD was $36-59 \mathrm{mg} / l$ and BOD / $\mathrm{NOx}-\mathrm{N}$ ratio 2.1-3.2. Influent $\mathrm{BOD}$ was relatively low in expriments at the water temperapure of $10^{\circ} \mathrm{C}$. The amount of hydrogen donor necessary for denitrification reaction ( $\mathrm{BOD} / \mathrm{NO} \mathrm{x}-\mathrm{N}$ ratio) is generally reported to be more than $2.0^{4)}$, so that hydrogen donor was thought to be sufficient. Effluent BOD was 7-17 $\mathrm{mg} / l$ without any correlation with $\mathrm{NOx}-\mathrm{N}$ concentration. BOD removal rate was not influenced by the water temperature, $0.51-0.54$ $\mathrm{g} / l \cdot \mathrm{d}$ in Run $1,0.27-0.35 \mathrm{~g} / l \cdot \mathrm{d}$ in Run 2 and $0.10-0.15 \mathrm{~g} / l \cdot \mathrm{d}$ in Run 3.

Influence of water temperature $\mathrm{NOx}-\mathrm{N}$ loading rate, $\mathrm{NOx}-\mathrm{N}$ removal rate and $\mathrm{NOx}-\mathrm{N}$ removal efficiency are shown in Table $5 . \mathrm{NOx}-\mathrm{N}$ loading rate in Table 5 indicates $\mathrm{NO}_{3}-\mathrm{N}$ loading rate. $\mathrm{NOx}-\mathrm{N}$ removal rate and $\mathrm{NOx}-\mathrm{N}$ removal efficiency were calculated from the $\mathrm{NOx}^{-\mathrm{N}}$ loading rate and the amount of the effluent $\mathrm{NOx}-\mathrm{N}$.

In order to evaluate the influence of water 
Table 3 Flow rate and water quality of influent

\begin{tabular}{|c|c|c|c|c|c|c|c|}
\hline Experiment & $\begin{array}{c}\text { Water } \\
\text { temperature } \\
\left({ }^{\circ} \mathrm{C}\right)\end{array}$ & Run & $\begin{array}{c}\mathrm{NO}_{3}-\mathrm{N} \\
(\mathrm{mg} / l)\end{array}$ & $\begin{array}{l}\text { BOD } \\
(\mathrm{mg} / l)\end{array}$ & $\underset{(\mathrm{mg} / l)}{\text { Alkalinity }}$ & $\mathrm{pH}$ & $\begin{array}{l}\text { Influent } \\
\text { flow rate } \\
(l / d)\end{array}$ \\
\hline \multirow{3}{*}{1} & \multirow{3}{*}{30} & 1 & 16.4 & 45 & 75 & 7.5 & 14.7 \\
\hline & & 2 & 16.1 & 45 & 71 & 7.5 & 7.5 \\
\hline & & 3 & 15.4 & 37 & 80 & 7.6 & 3.9 \\
\hline \multirow{3}{*}{2} & \multirow{3}{*}{20} & 1 & 17.8 & 50 & 63 & 7.4 & 15.6 \\
\hline & & 2 & 19.6 & 59 & 69 & 7.4 & 7.0 \\
\hline & & 3 & 16.5 & 53 & 68 & 7.6 & 4.1 \\
\hline \multirow{3}{*}{3} & \multirow{3}{*}{10} & 1 & 17.5 & 44 & 64 & 7.2 & 16.0 \\
\hline & & 2 & 17.3 & 41 & 65 & 7.3 & 8.0 \\
\hline & & 3 & 17.3 & 36 & 70 & 7.4 & 4.1 \\
\hline
\end{tabular}

Table 4 Water quality of effluent

\begin{tabular}{|c|c|c|c|c|c|c|c|}
\hline Experiment & $\begin{array}{c}\text { Water } \\
\text { temperature } \\
\left({ }^{\circ} \mathrm{C}\right)\end{array}$ & Run & $\begin{array}{c}\mathrm{NO}_{2}-\mathrm{N} \\
(\mathrm{mg} / l)\end{array}$ & $\begin{array}{c}\mathrm{NO}_{3}-\mathrm{N} \\
(\mathrm{mg} / l)\end{array}$ & $\begin{array}{l}\text { BOD } \\
(\mathrm{mg} / l)\end{array}$ & $\begin{array}{l}\text { Alkalinity } \\
(\mathrm{mg} / l)\end{array}$ & $\mathrm{pH}$ \\
\hline \multirow{3}{*}{1} & \multirow{3}{*}{30} & 1 & 1.6 & 2.9 & 8 & 133 & 8.1 \\
\hline & & 2 & 0.7 & 1.6 & 9 & 142 & 8.1 \\
\hline & & 3 & 0.1 & 0.6 & 11 & 149 & 8.1 \\
\hline \multirow{3}{*}{2} & \multirow{3}{*}{20} & 1 & 4.1 & 6.2 & 15 & 104 & 7.7 \\
\hline & & 2 & 4.3 & 3.2 & 9 & 139 & 8.0 \\
\hline & & 3 & 1.8 & 1.2 & 17 & 139 & 8.1 \\
\hline \multirow{3}{*}{3} & \multirow{3}{*}{10} & 1 & 5.3 & 9.0 & 12 & 92 & 7.5 \\
\hline & & 2 & 3.5 & 8.6 & 7 & 98 & 7.7 \\
\hline & & 3 & 2.5 & 9.3 & 11 & 99 & 7.8 \\
\hline
\end{tabular}

Table 5 NOx-N removal efficiency

\begin{tabular}{c|c|c|c|c}
\hline $\begin{array}{c}\text { Water temperature } \\
\left({ }^{\circ} \mathrm{C}\right)\end{array}$ & Run & $\begin{array}{c}\text { NOx-N loading } \\
\text { rate }(\mathrm{g}-\mathrm{N} / l \cdot \mathrm{d})\end{array}$ & $\begin{array}{c}\text { NOx-N removal } \\
\text { rate }(\mathrm{g}-\mathrm{N} / l \cdot \mathrm{d})\end{array}$ & $\begin{array}{c}\text { NOx-N removal } \\
\text { efficiency }(\%)\end{array}$ \\
\hline \multirow{3}{*}{30} & 1 & 0.241 & 0.175 & 72.6 \\
\cline { 2 - 5 } & 2 & 0.121 & 0.104 & 85.9 \\
\cline { 2 - 5 } & 3 & 0.060 & 0.057 & 95.0 \\
\cline { 2 - 5 } & 1 & 0.277 & 0.117 & 42.2 \\
\cline { 2 - 5 } & 2 & 0.137 & 0.085 & 62.0 \\
\cline { 2 - 5 } & 3 & 0.068 & 0.055 & 80.9 \\
\cline { 2 - 5 } & 1 & 0.280 & 0.051 & 30.2 \\
\cline { 2 - 5 } & 2 & 0.138 & 0.042 & 32.4 \\
\hline \multirow{2}{*}{10} & 3 & 0.071 & 0.023 & \\
\hline
\end{tabular}




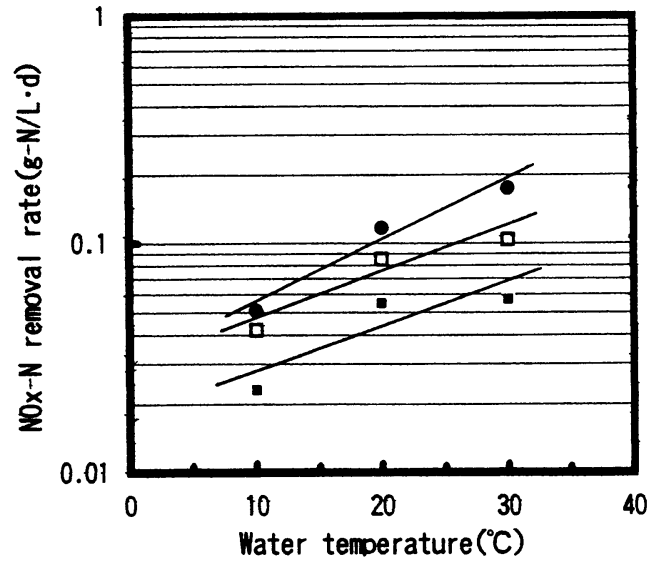

Fig.2 Relationship between water temperature and NOx-N removal rate.Symbols : $0.24 \mathrm{~g}-\mathrm{N} / / \cdot \mathrm{d} ; \square, 0.12 \mathrm{~g}-\mathrm{N} / / \cdot \mathrm{d} ; \square$, $0.06 \mathrm{~g}-\mathrm{N} / \mathrm{I} \cdot \mathrm{d}$.

temperature on denitrification efficiency, the relationship between the $\mathrm{NOx}-\mathrm{N}$ removal rate and water temperature was shown in Fig.2. Under each $\mathrm{NOx}-\mathrm{N}$ loading condition, the $\mathrm{NO}-\mathrm{N}$ removal rate was apparently influenced by water temperature. Temperature coefficients $(\theta)^{5)}$ were calculated to be 1.064 in Run 1, 1.046 in Run 2 and 1.046 in Run 3 as the slope of the lines shown in Fig.2. Since the influence of water temperature was stronger on treatment under $\mathrm{NOx}-\mathrm{N}$ loading rate of $0.24 \mathrm{~g} / l \cdot \mathrm{d}$ than under $\mathrm{NOx}-\mathrm{N}$ loading rate less than $0.12 \mathrm{~g} / l \cdot \mathrm{d}$, this would indicate a difficulty in obtaining a high denitrification efficiency under high $\mathrm{NOx}-\mathrm{N}$ loading rate at low water temperature.

As the results of denitrification in a waste water treatment facility by using activated sludge process, the following equation was reported to indicate the relationship between denitrification rate $(\mathrm{K}: \mathrm{mg}-\mathrm{N} / \mathrm{g}-\mathrm{ss} \cdot \mathrm{hr})$ and water temperature $\left(\mathrm{T}:{ }^{\circ} \mathrm{C}\right)^{6}$.

$$
\mathrm{K}=0.324 \cdot \mathrm{e}^{0.0634 \mathrm{~T}} \text {. }
$$

The relationship between denitrification rate and water temperature in anoxic reactor by a submerged bed process using net-like contact media was reported as follows ${ }^{7)}$ :

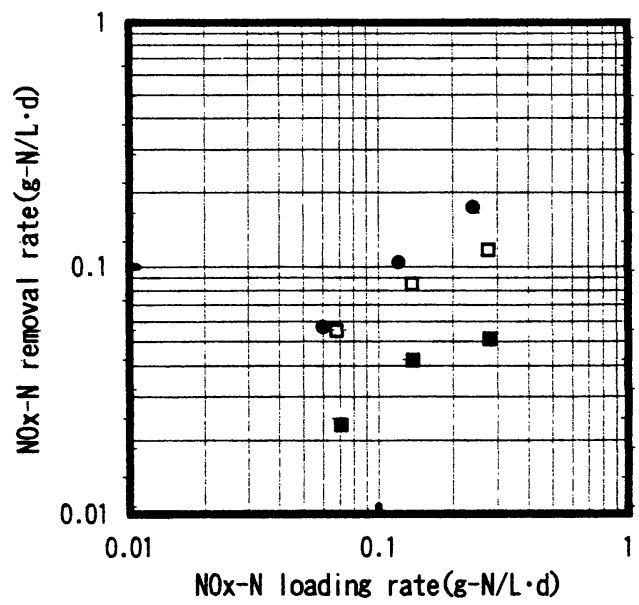

Fig.3 Relationship between NOx-N loading rate and NOx-N removal rate.Symbols: , $30^{\circ} \mathrm{C} ; \square, 20^{\circ} \mathrm{C} ; \square, 10^{\circ} \mathrm{C}$.

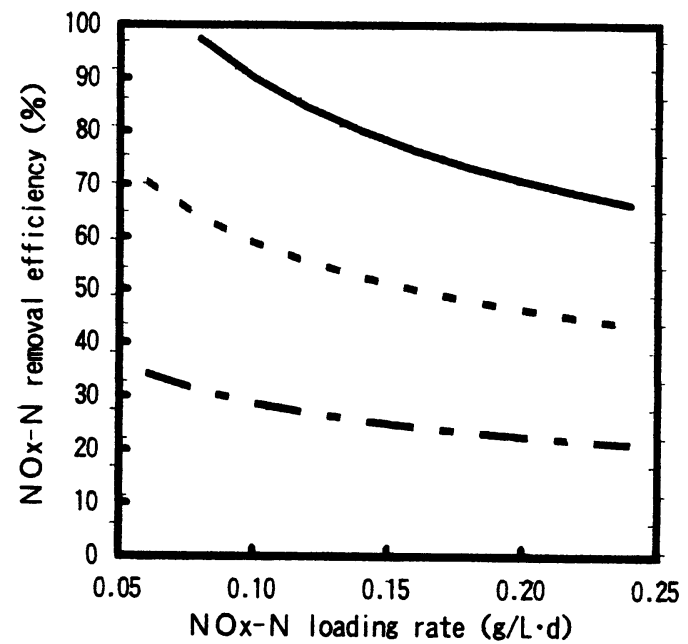

Fig.4 Relationship between NOx-N loading rate and $\mathrm{NOx}-\mathrm{N}$ removal efficiency. $\longrightarrow, 30^{\circ} \mathrm{C} ;---20^{\circ} \mathrm{C} ;---, 10^{\circ} \mathrm{C}$.

$$
\mathrm{K}=1.98 \cdot \mathrm{e}^{0.04 \mathrm{~T}}
$$

Based on equations (1) and (2), a fall of denitrification rate by approximately $1 / 2-2 / 3$ on a decrease of water temperature by $10^{\circ} \mathrm{C}$ is suggested. Anoxic reactor using lace-like contact media such as the reactor used in this study was therefore assumed to be influenced by water temperature to a similar degree.

Relationship between NOx-N loading rate and 
NOx $-\mathrm{N}$ removal efficiency The relationship between the $\mathrm{NOx}-\mathrm{N}$ load and $\mathrm{NOx}-\mathrm{N}$ removal rate was shown in Fig.3. A strong correlation was observed between the $\mathrm{NOx}-\mathrm{N}$ load and $\mathrm{NO} x-\mathrm{N}$ removal rate. This relationship was greatly affected by water temperature.

To study the effect of $\mathrm{NOx}-\mathrm{N}$ load and water temperature on $\mathrm{NOx}-\mathrm{N}$ removal rate, the relationships between the $\mathrm{NOx}-\mathrm{N}$ removal rate, the $\mathrm{NOx}-\mathrm{N}$ load and water temperature were expressed by the following multiple regression equations:

$$
\begin{aligned}
& \ln (Z)=0.65 \cdot \ln (\mathrm{X})+1.04 \cdot \ln (\mathrm{Y})-4.42 \\
& Z=0.012 \cdot X^{0.65} \cdot Y^{1.04}
\end{aligned}
$$

where $Z: N O x-N$ removal rate $(g / l \cdot d)$

$\mathrm{X}: \mathrm{NOx}-\mathrm{N}$ loading rate $(\mathrm{g} / \mathrm{l} \cdot \mathrm{d})$

$\mathrm{Y}$ : water temperature $\left({ }^{\circ} \mathrm{C}\right)$

When the $\mathrm{NOx}-\mathrm{N}$ removal efficiency is designated $r, r=Z / X \cdot 100$. Substituting this equation into Equation (4) resulted in the following Equation:

$$
\mathrm{r}=1.2 \cdot \mathrm{X}^{-0.35} \cdot \mathrm{Y}^{1.04}
$$

By substituting $\mathrm{X}$ in Equation (5) with different values of $\mathrm{NO} x-\mathrm{N}$ load, $\mathrm{NO} x-\mathrm{N}$ removal efficiencies were calculated. The relationship between $\mathrm{NOx}-\mathrm{N}$ loading rate and $\mathrm{NOx}-\mathrm{N}$ removal efficiency at a given temperature is shown in Fig.4. The value is greatly affected by water temperature.

Denitrification rate After the end of the experiment at water temperature of $30^{\circ} \mathrm{C}$, the weight of attached biomass was estimated in each reactor as shown in Table 6. At the water temperature of $30^{\circ} \mathrm{C}$, denitrification rates were

Table 6 Biomass in anoxic tank and denitrification rate of each system at water temperature of $30^{\circ} \mathrm{C}$

\begin{tabular}{c|c|c|c}
\hline \multirow{2}{*}{ Run } & \multirow{2}{*}{$\begin{array}{c}\text { Biomass } \\
\text { concentration } \\
\end{array}$} & \multicolumn{2}{|c}{ Denitrification rate } \\
\cline { 3 - 4 }$(\mathrm{mg}-\mathrm{SS} / l)$ & $(\mathrm{g}-\mathrm{N} / l \cdot \mathrm{d})$ & $(\mathrm{mg}-\mathrm{N} / \mathrm{g}-\mathrm{SS} \cdot \mathrm{hr})$ \\
\hline 1 & 1642 & 0.175 & 4.46 \\
\hline 2 & 1359 & 0.104 & 3.19 \\
\hline 3 & 999 & 0.057 & 2.38 \\
\hline
\end{tabular}

2.4-4.5 mg-N/g-SS· hr.

Denitrification rate was reported to be $0.5-4.0$ $\mathrm{mg}-\mathrm{N} / \mathrm{g}-\mathrm{SS} \cdot \mathrm{hr}$ (at water temperature of

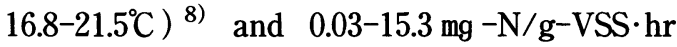
$\left(20^{\circ} \mathrm{C}\right)^{2)}$ by using oxidation ditch processes, 1.20 $\mathrm{mg}-\mathrm{N} / \mathrm{g}-\mathrm{VSS} \cdot \mathrm{hr}\left(20^{\circ} \mathrm{C}\right)^{9)}$ in a fluidized bed system using ceramic carriers of $0.5 \mathrm{~mm}$ in diameter and $0.03-5.0 \mathrm{mg}-\mathrm{N} / \mathrm{g}-\mathrm{SS} \cdot \mathrm{hr}\left(25^{\circ} \mathrm{C}\right)$ in a reactor using submerged bed process equipped with net-like contact media ${ }^{7)}$.

Since the results obtained in this denitrification experiment using submerged bed process equipped with lace-like contact media were comparable with those obtained by using anoxic reactor in other systems, the reactor using lace-like contact media is thought to be capable of growing the microorganism necessary for denitrification treatment.

\section{CONCLUSION}

$\mathrm{NO} x-\mathrm{N}$ removal experiments using anoxic reactors equipped with lace-like contact media were conducted under various $\mathrm{NOx}-\mathrm{N}$ loading conditions and water temperatures. The following results were obtained.

(1) Temperature coefficients $(\theta)$ were calculated to be $1.046-1.064$. The influence of water temperature was stronger on treatment under higher $\mathrm{NOx}-\mathrm{N}$ loading rate than under lower $\mathrm{NO} x-\mathrm{N}$ loading rate.

(2) Equation expressing the relationships between the $\mathrm{NOx}-\mathrm{N}$ removal rate, the $\mathrm{NOx}-\mathrm{N}$ loading rate and water temperature was obtained. Transformation of this equation resulted in the equation which expresses the relationships between $\mathrm{NOx}-\mathrm{N}$ removal efficien$\mathrm{cy}, \mathrm{NO}-\mathrm{N}$ loading rate and water temperature. The NOx-N loading rate in the anoxic reactor which permits a high $\mathrm{NOx}-\mathrm{N}$ removal efficiency can be estimated from the equation. The value is greatly affected by water temperature.

(3) Denitrification rate was $2.4-4.5 \mathrm{mg}-\mathrm{N} / \mathrm{g}-$ $\mathrm{SS} \cdot \mathrm{hr}$ at a water temperature of $30^{\circ} \mathrm{C}$, increas- 
ing in proportion to the rise of $\mathrm{NOx}-\mathrm{N}$ loading rate. Since the results obtained in this experiment were simmilar to those reported by using anoxic reactor of other systems, microorganisms are probably capable of growing sufficient for denitrification in the reactor equipped with lace-like contact media.

\section{REFERENCE}

1 ) Kashimura T. and Tsuchiya F. :The Characteristics and Applications of Ring Lace Contact Media, J.Water and Waste,23, 4, 18-21, (1981) (in Japanese)

2 ) Nishijima W.,Okada M. and Sudo R. : Simuration studies on simultaneous removal of nitrogen, phosphorus and organic substances by oxidation ditch process, Japan Journal of Water Pollution Reseach, 10, 609-617, (1987) (in Japanese)

3 ) Standard mathods for the examination of wastewater, (1984) (in Japanese)

4 ) Takahara Y. : Biologocal Waswewater Treatment, Chikyu-sha, 315 (1980) (in Japanese)

5 ) Horasawa I. : Biologocal Waswewater Treatment, Gihodo, 191-193, (1976) (in Japanese)
6) Japan Constraction Center Foundation : Report on the Procedure of Evaluation of Handling of Nitrogen, Phosphorus and Organic Substances in Onsite wastewater treatment system. (1987) (in Japanese)

7 ) Ide M. and Muto N. : Experimental Study on Recirculation Ratio and Related Factors in Biological Nitrification/Denitrification Process for Onsite Houshold Wastewater Treatment Facilities,Part 2- Effect of Temperature in Nitrification and Denitrification Reaction, Transactions of the Society of Heating,Air-Conditioning and Sanitary Engineers of Japan,55, 45-55, (1994) (in Japanese)

8 ) Simizu T.,Kudo K.,Doro T.,Nasu Y. :Optimum Oxygen Supply for Nitrogen Removal in an Oxidation-Ditch, J.Japan Society on Water Environment,15, (8) , 519-526, (1992) (in Japanese)

9 ) Ando S.,Ichida T. : Continuous Removal of TOC and T-N by Aerobic-Microaerophilic System Using Bioparticle,Proceedings 27th JSWE Annual Technical Conference, 160-161, (1993) (in Japanese)

(Submitted 1994.10.11)

(Accepted 1994.12.13) 